УДК 547.022.1

\title{
Effect of Lignin on the Properties of Organic and Carbon Gels from Polyphenols \\ of the Larch Bark
}

\author{
Nadezhda M. Mikova*, \\ Galina P. Skvortsova, Ivan P. Ivanov, \\ Vladimir A. Levdansky and Boris N. Kuznetsov \\ Institute of Chemistry and Chemical Technology SB RAS \\ FRC "Krasnoyarsk Science Center SB RAS" \\ 50/24 Akademgorodok, Krasnoyarsk, 660036, Russia
}

Received 19.02.2017, received in revised form 28.05.2017, accepted 14.07.2017

The influence of lignin on the properties of organic and carbon gels synthesized by sol-gel polymerization of a mixture of formaldehyde and polyphenols isolated by various solvents from the larch bark was investigated.

The porous structure and adsorption properties of polymer gels synthesized from mixtures of formaldehyde and ethanol extracts of bark by varying the $\mathrm{pH}$ value of initial solutions in the range of 4 to 12 were studied by BET and SEM methods. It was shown that an increase in $p H$ value leads to the formation of organic gels with a more compacted texture and narrow pores. Carbonization of organic gels at $900{ }^{\circ} \mathrm{C}$ promotes the significant development of the specific surface area (up to $477 \mathrm{~m}^{2} / \mathrm{g}$ ) of the obtained carbon gels.

It was found that the addition of lignin in an amount of $10 \% \mathrm{wt}$. to the polyphenols extracted by water from the larch bark improves the texture characteristics of the obtained organic and carbon gels and increases theirs elasticity and strength. But the increase of the lignin content to 20-30\% wt. reduces the total porosity and the total pore volume of the obtained gels. The effect of lignin on the properties of gels, obtained with the use of polyphenols extracted from larch bark by water-alkaline solution, is less pronounced.

Keywords: lignin, larch polyphenols, organic and carbon gel, texture and adsorption properties.

DOI: $10.17516 / 1998-2836-0033$.

(C) Siberian Federal University. All rights reserved

* Corresponding author E-mail address: nm@icct.ru 


\title{
Влияние лигнина на свойства органических \\ и углеродных гелей \\ из полифенолов коры лиственницы
}

\author{
Н.М. Микова, Г.П. Скворцова, \\ И.П. Иванов, В.А. Левданский, Б.Н. Кузнецов \\ Институт химии и химической технологии СО РАН \\ ФИЦ «Красноярский научный цуентр СО РАН» \\ Россия, 660036, Красноярск, Академгородок, 50/24
}

Исследовано влияние лигнина на свойства органических и углеродных гелей, синтезированных золь-гель-полимеризачией смеси формальдегида и полифенолов, выделенных различными растворителями из коры лиственницы.

Методоми БЭТ и СЭМ изучена пористая структура и адсорбиионные свойства полимерных гелей, полученных из смесей формальдегида и этанольных экстрактов коры при варьировании величины рН исходных растворов в интервале значений от 4 до 12. Показано, что повышение величины рН приводит к формированию органических гелей с более плотной текстурой и узкими порами. Карбонизация органических гелей при $900{ }^{\circ} \mathrm{C}$ способствует значительному развитию удельной поверхности (до $477 \mathrm{M}^{2} / 2$ ) получаемых углеродных гелей.

Установлено, что добавление лигнина в количестве $10 \%$ вес. к полифенолам, извлеченным водой из коры лиственницы, улучшает текстурные характеристики получаемых органических и углеродных гелей, а также повышает их упругость и прочность. Однако увеличение содержания лигнина до 20-30 \% вес. приводит к уменьшению общей пористости и общего пористого объема получаемых гелей. Влияние лигнина на свойства гелей, полученных с использованием полифенолов, извлеченных из коры лиственницы водно-щелочным раствором, менее выражено, чем при использовании водных полифенолов.

Ключевые слова:лигнин, полифенолылиственнищьы, органический иуглеродныйгель, текстурные и адсорбиионные свойства.

\section{Введение}

В настоящее время сохраняется актуальность поиска относительно недорогих сырьевых источников из возобновляемых растительных ресурсов для получения на их основе коммерчески привлекательных продуктов с высокой добавленной стоимостью. Перспективные направления переработки биомассы лиственницы основаны на использовании ценных экстрактивных веществ, выделенных из древесины и коры.

Особое внимание исследователей привлекает возможность использования конденсированных таннинов (полифенольных соединений) для синтеза органических и углеродных аэрогелей. Свойства таннинов зависят от их природы, а также от способа и условий их выделения [1]. Извлечение полифенольных веществ из древесной коры производят с применением различ-

$$
-369-
$$


ных экстрактов: этанола, горячей воды, водно-этанольного раствора щелочи или органических растворителей $[2,3]$.

Выделяемые из древесины коры таннины могут использоваться в качестве источника, альтернативного дорогому резорцину и токсичному фенолу, широко используемым для получения полимерных гелей с уникальными свойствами [4]. Важное преимущество использования полифенолов древесной коры состоит в их возобновляемой природе, низкой стоимости и экологической безопасности.

Полимерные гели представляют собой специфический класс материалов органической или углеродной природы, полученных путем золь-гель-конденсации фенольных соединений с альдегидами [5]. В основном это мезопористые материалы с преимущественным размером пор 2-50 нм, которые обладают, как правило, низкой плотностью, большой пористостью, высокой удельной поверхностью. Все это открывает широкие перспективы для их использования в различных областях [6].

Лигнин также является потенциальным источником фенолов и может применяться для замены резорцина и фенола или использоваться как реагент, способный самостоятельно либо в качестве сополимера с таннинами участвовать в реакциях конденсации [7-9]. Однако имеющиеся в литературе сведения об использовании лигнина для приготовления полимерных гелей весьма ограничены. Среди доступных технических лигнинов особый интерес представляют лигносульфонаты, образующиеся в качестве отхода в процессах сульфатной варки целлюлозы. Лигносульфонаты склонны к реакциям комплексообразования [10], и можно ожидать, что их использование в качестве сополимера в реакциях конденсации полифенолов с формальдегидом позволит получать полимерные материалы с новыми свойствами.

Целью работы являлось изучение пористой структуры и свойств новой группы полимерных гелей, получаемых реакциями поликонденсации формальдегида и полифенолов коры лиственницы, а также их смесей с техническим лигнином, представленным лигносульфонатами.

\section{Материалы и методы}

Для получения полимерных гелей использовались полифенолы, выделенные из коры лиственницы путём экстрагирования этанольным, либо водным, либо 0,5\%-м водным раствором $\mathrm{NaOH}$. Содержание использованных для приготовления аэрогелей полифенольных веществ в коре лиственнице, представленных преимущественно конденсированными пирокатехиновыми таннинами, составляло 11-13 \% вес (в пересчете на а.с. кору). Средняя молекулярная масса полифенольных веществ лиственницы равна 1680 Да.

При получении гелей из смеси полифенолы-лигнин использовали лигносульфонаты, полученные в процессе сульфитной делигнификации древесины ели (ТУ 13-0281036-029-94 [10]). Состав лигносульфонатов, \% вес.: $\mathrm{C}-48,4 ; \mathrm{H}-5,24 ; \mathrm{S}-5,5 ; \mathrm{N}-0,5$ (на а.с. в.), зольность - 15,4. Средняя молекулярная масса лигносульфонатов равна 50 кДа.

Для приготовления полимерных гелей полифенолы лиственницы растворяли в подходящем растворителе до требуемой концентрации, смешивали в массовом соотношении 1:1,5 с 40\%-м водным раствором формальдегида, варьировали рН реакционной среды в интервале 4-12 добавлением требуемых количеств $\mathrm{NaOH}$ или $\mathrm{H}_{2} \mathrm{SO}_{4}$ и выдерживали смесь при температу-

$$
-370-
$$


pe $85{ }^{\circ} \mathrm{C}$ в течение 5 сут. Образовавшиеся продукты извлекали, помещали в этанол, где в течение 3 сут проводили полное замещение воды из пор геля на спиртовую фазу. Сушку проводили сначала при пониженной температуре (минус $18-20^{\circ} \mathrm{C}$ ) в течение суток, при комнатной температуре и окончательно в вентилируемом сушильном шкафу при последовательном подъёме температуры от 30 до $90{ }^{\circ} \mathrm{C}$.

Получение углеродных гелей (УГ) осуществляли путем карбонизации органических гелей в продуваемой аргоном трубчатой печи «Варта», с терморегулятором-измерителем программируемого типа ТП 703. Температура карбонизации составляла $900{ }^{\circ} \mathrm{C}$, изотермическая выдержка 2 ч. Скорость нагрева печи $5{ }^{\circ} \mathrm{C} / \mathrm{мин.}$

Элементный состав исследуемых образцов определяли с помощью анализатора HCNS-0 EA 1112 (Flash, США).

Регистрацию ИК-спектров в области длин волн 400-4000 см ${ }^{-1}$ выполняли на ИК-Фурье спектрометре Bruker Tensor-27 Красноярского регионального центра коллективного пользования СО РАН. Твердые образцы (5 мг) для анализа готовили в виде таблеток в матрице $\mathrm{KBr}$.

Текстурные характеристики органических и углеродных гелей измеряли методом равновесной адсорбции-десорбции азота при $77 \mathrm{~K}$ в диапазоне относительных давлений $\mathrm{P} / \mathrm{P}_{0}$ от 0,005 до 0.995 на анализаторе ASAP 2020 (Micromeritics, США). Для определения удельной площади

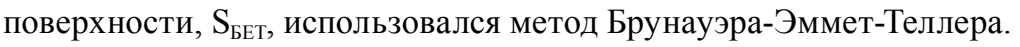

\section{Результаты и их обсуждение}

\section{Органические гели из полифенолов коры лиственницы}

Органические гели получали из смеси формальдегида и полифенолов, извлеченных этанолом из коры лиственницы. Гели, полученные при вариации рН среды от 4 до 12, обозначены как ОГЛ 4 - ОГЛ 12. Повышение величины $\mathrm{pH}$ раствора исходной смеси приводит к изменению внешнего вида получаемых гелей, которые становятся более плотными и приобретают более темный вид.

ИК-спектры образцов органических гелей содержат полосы поглощения, характерные для ароматических колец (при 1613, 1516 и 1448 см с $^{-1}$ ), эфирных, спиртовых (1110-1277 см-1) и фенольных оксигрупп. Характерной особенностью спектров ОГЛ является высокая интенсивность полос поглощения при 2929, $2852 \mathrm{~cm}^{-1}$, что в сочетании с поглощением при $1460 \mathrm{~cm}^{-1}$ указывает на значительное содержание алифатических, в том числе метиленовых, $\mathrm{CH}_{2}-$ групп [11].

Полученные образцы ОГЛ характеризуются относительно невысокими значениями удельной поверхности и объема пор (7-23 м²/г и 0,05-0,1 см $3 / \Gamma$ соответственно). В зависимости от $\mathrm{pH}$ исходных растворов полимерные гели отличаются большим разбросом по плот-

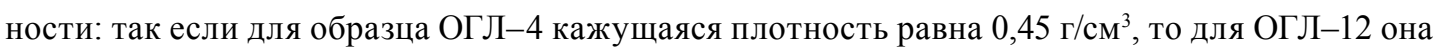

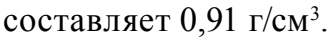

Методом БЭТ установлено, что полученные органические гели относятся, главным образом, к макро-/мезопористым материалам [5,7]. Представленные на рис. 1 изотермы адсорбции-десорбции азота на образцах органических гелей, приготовленных при различных $\mathrm{pH}$, описывают типичную мезопористую структуру (IV типа) с характерной десорбционной ветвью.

$$
-371-
$$




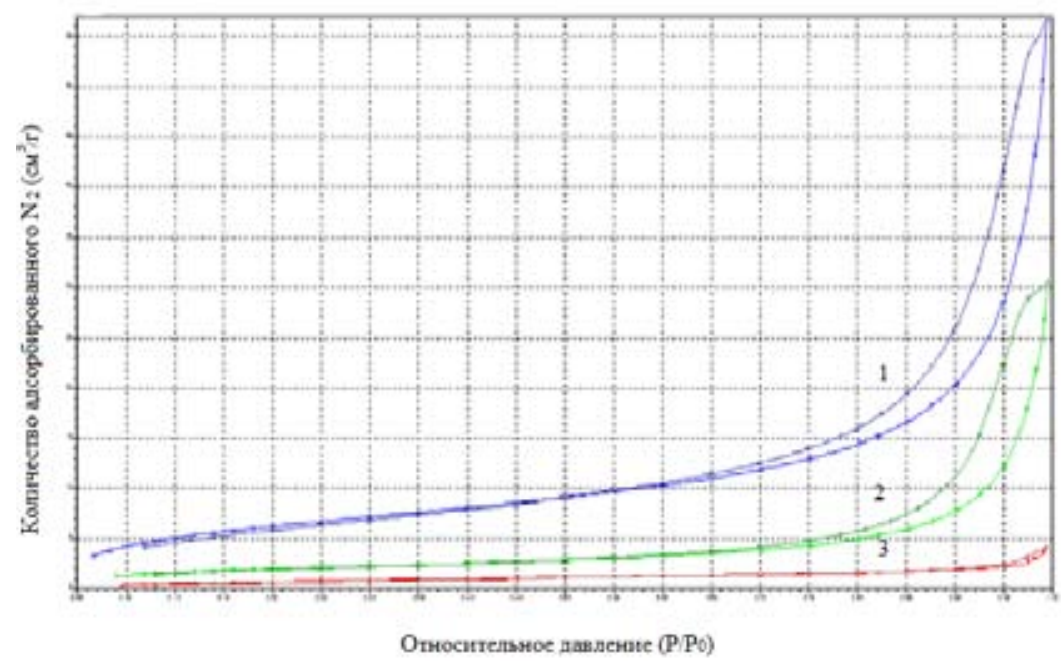

Рис. 1. Изотермы адсорбции-десорбции азота на образцах ОГЛ, приготовленных при различных значениях рH: $1-4 ; 2-6,3-10$

Fig. 1. Isotherms of nitrogen adsorption-desorption on the samples of OGL prepared at the different $\mathrm{pH}$ values: $1-4 ; 2-6,3-10$

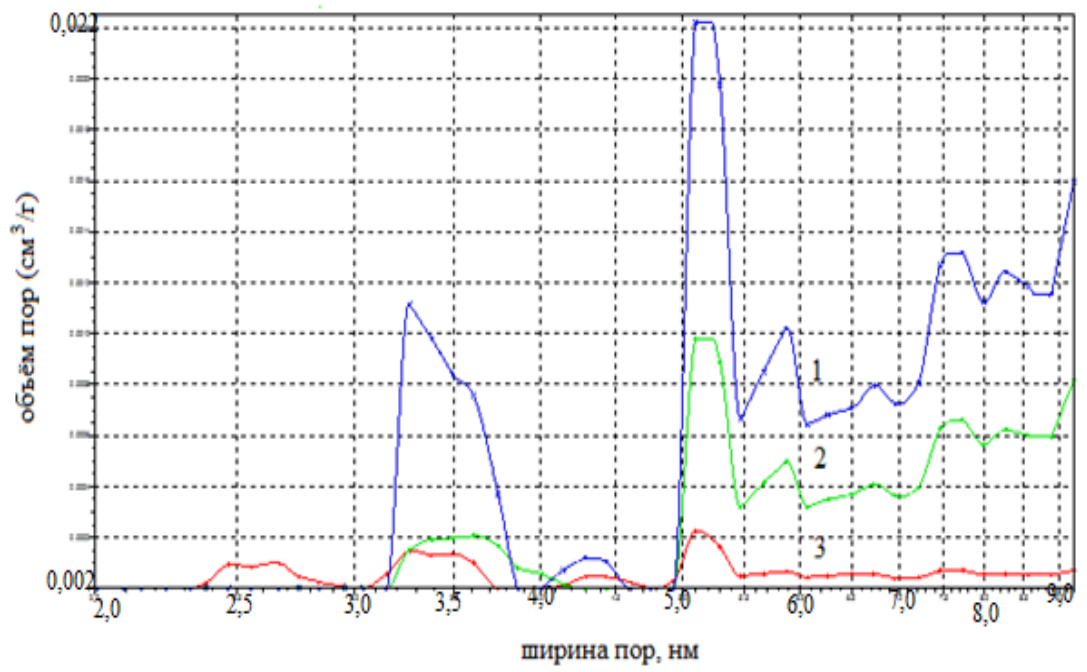

Рис. 2. Зависимость объёма пор от ширины пор для образцов ОГЛ, полученных при различных значениях $\mathrm{pH}: 1-4 ; 2-6,3-10$

Fig. 2. Dependence of the pore volume on the pore width in the samples of OGL obtained at different $\mathrm{pH}$ values: $1-4 ; 2-6,3-10$

Как следует из характера распределения пор по размерам и занимаемого ими объема (рис. 2), образец, приготовленный при $\mathrm{pH}=4$, демонстрирует широкое разнообразие пор размером свыше 3,15 нм во всём изученном диапазоне ( $\leq 10$ нм).

Самый интенсивный пик распределения приходится на поры шириной 4,9-5,5 нм, однако имеются как поры меньшего размера, так и более широкие поры. В этом же интервале распределяются поры у образца, приготовленного при $\mathrm{pH}=6$, с той лишь разницей, что большая 
часть пор находится в области значений свыше 4,9 нм. Отличительной особенностью образца, полученного при $\mathrm{pH}=10$, является более узкое распределение пор с невысокой интенсивностью максимумов в интервале 2,3-5,5 нм.

Таким образом, повышение $\mathrm{pH}$ среды способствует формированию органических гелей с более плотной текстурой и более узкими порами.

Результаты изучения методом СЭМ образца органического геля, синтезированного при pH 4, свидетельствует о том, что его поверхность сформирована из относительно однородных частиц размером около $10 \mu \mathrm{m}$, образующих мелкоячеистую структуру. Имеются также включения из более крупных агрегированных частиц размером 30-50 мкм.

\section{Углеродные гели из полифенолов коры лиственнищьы}

Карбонизация органических гелей (аргон, $900{ }^{\circ} \mathrm{C}, 2$ ч) способствует развитию удельной поверхности и объёма пор образующихся углеродных материалов. На рис. 3 приведены изотермы адсорбции-десорбции азота (77 К) на образцах углеродных гелей (УГ), полученных путем карбонизации органических гелей ОГЛ-4, ОГЛ-6 и ОГЛ-10.

Формы изотерм характерны для микропористых систем (I типа), однако наличие десорбционной ветви свидетельствует о вкладе мезопор в пористую текстуру углеродных гелей.

Результаты изучения пористой структуры углеродных гелей (табл. 1) показали, что наиболее высокими значениями удельной поверхности и суммарного объема пор отличается образец, приготовленный из органического геля, синтезированного при $\mathrm{pH}$, равном 4. Изменение величины $\mathrm{pH}$ исходной смеси с 4 до 10 приводит к значительному снижению удельной поверхности (с 477 до 107 м²/г) и общего объема пор (с 0,33 до 0,08 г/см³).

Методом СЭМ изучена морфология поверхности углеродных гелей. На рис. 4 представлен электронно-микроскопический снимок образца УГ-4 с типичным узелковым стро-

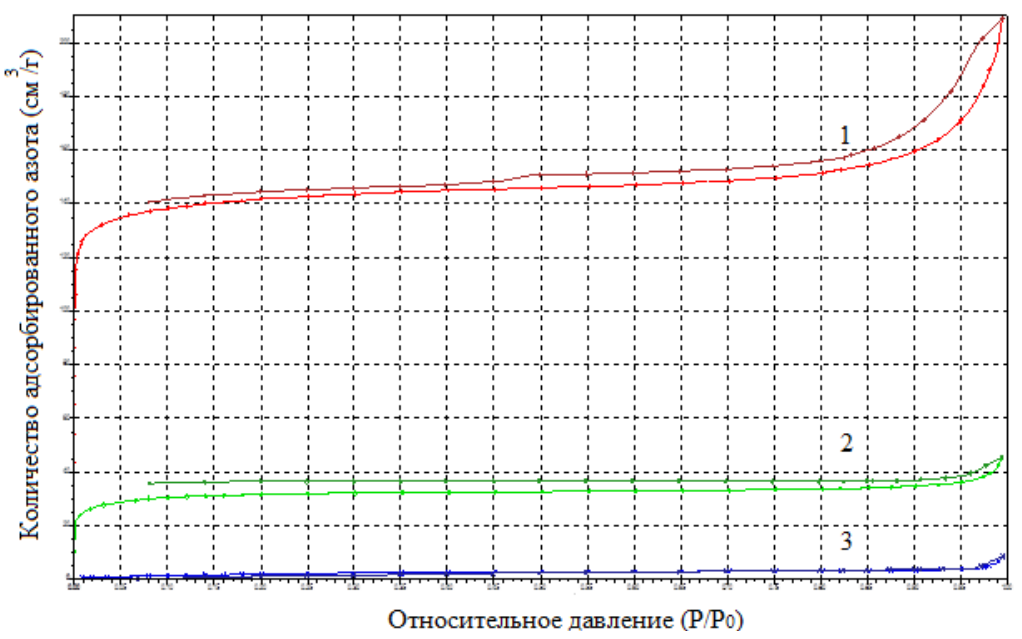

Рис. 3. Изотермы адсорбции-десорбции азота на углеродных гелях, полученных карбонизацией ОГЛ, синтезированных при различных значениях $\mathrm{pH}: 1-4 ; 2-6,3-10$

Fig. 3. Isotherms of nitrogen adsorption-desorption on the carbon gels obtained by carbonization of the OGL synthesized at different $\mathrm{pH}$ values: $1-4 ; 2-6,3-10$ 
ением тесно связанных между собой сферических частиц, размер которых не превы-шает $1 \mu \mathrm{m}$.

Методом БЭТ изучены особенности пористой структуры углеродных гелей. На рис. 5 изображены кривые распределения объема пор в зависимости от их ширины. Для образца УГ-4 характерно самое широкое распределение пор - наряду с узкими микропоры размером менее 1 нм в этом образце также присутствуют мезо- и макропоры, вплоть до 70 нм. Ширина мезопор варьируется в интервале 3,5-50 нм с максимумом при 10 нм, вклад макропор незначителен.

Образцы УГ-6 и УГ-10 имеют более узкое распределение пор по размерам, с преобладанием мезопор шириной около 10 нм. Данные образцы, обладая в целом меньшей пористостью, чем УГ-4, имеют в своем составе близкое соотношение микро- и мезопор.

Таблица 1. Характеристики пористой структуры образцов углеродных гелей, полученных карбонизацией ОГЛ, синтезированных при различных $\mathrm{pH}$

Table 1. Characteristics of the porous structure of carbon gel samples obtained by carbonization of the OGL synthesized at different $\mathrm{pH}$

\begin{tabular}{|l|l|l|l|l|l|l|l|l|}
\hline №/№ & $\begin{array}{l}\text { Образец } \\
\text { углеродного } \\
\text { геля }\end{array}$ & $\begin{array}{l}\mathrm{pH} \\
\text { среды* }\end{array}$ & $\mathrm{S}_{\text {Бэт, }} \mathrm{M}^{2} / \Gamma$ & $\begin{array}{l}\text { Sмикро, } \\
\mathrm{M}^{2} / \Gamma\end{array}$ & $\begin{array}{l}\text { Уобщ } \\
\mathrm{cm}^{3} / \Gamma\end{array}$ & $\begin{array}{l}\text { Vмикро, } \\
\mathrm{cm}^{3} / \Gamma\end{array}$ & $\begin{array}{l}\text { Vмезо, ву } \\
\text { ВЈН }\end{array}$ & $\begin{array}{l}\text { Интервал } \\
\text { размера пор, нм }\end{array}$ \\
\hline 1 & УГ-2 & 2 & 31,95 & 30,12 & 0,02 & 0,014 & 0,004 & $2,28-7,98$ \\
\hline 2 & УГ-4 & 4 & 477,37 & 447,32 & 0,33 & 0,21 & 0,110 & $2,71-19,82$ \\
\hline 3 & УГ-6 & 6 & 259,33 & 232,26 & 0,23 & 0,11 & 0,100 & $3,49-12,1$ \\
\hline 4 & УГ-10 & 10 & 107,03 & 101,26 & 0,08 & 0,05 & 0,022 & $2,63-10,05$ \\
\hline 5 & УГ-12 & 12 & 34,2 & 32,875 & 0,014 & 0,01 & 0,005 & $2,04-5,87$ \\
\hline
\end{tabular}

* При синтезе ОГЛ.

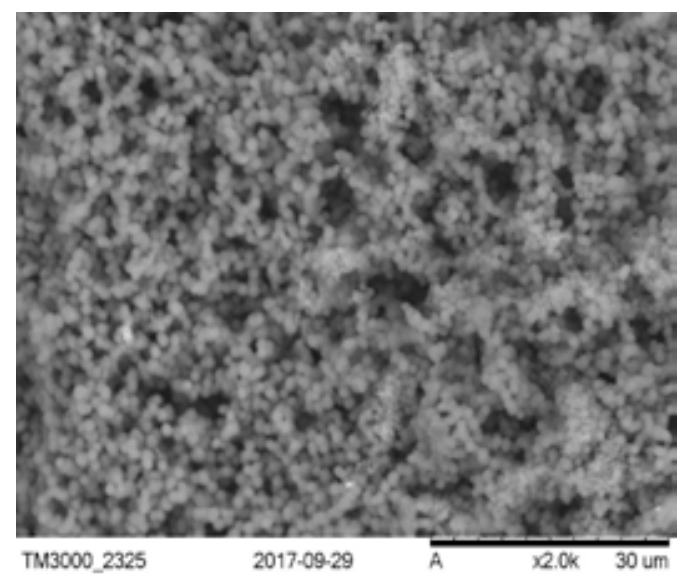

Рис. 4. Электронно-микроскопический снимок образца углеродного геля УГ-4, полученного карбонизацией ОГЛ-4 (увеличение 2000 раз)

Fig. 4. Electron microscopy image of the carbon gel UG-4 obtained by carbonization of the OGL-4 (magnification 2000 times) 


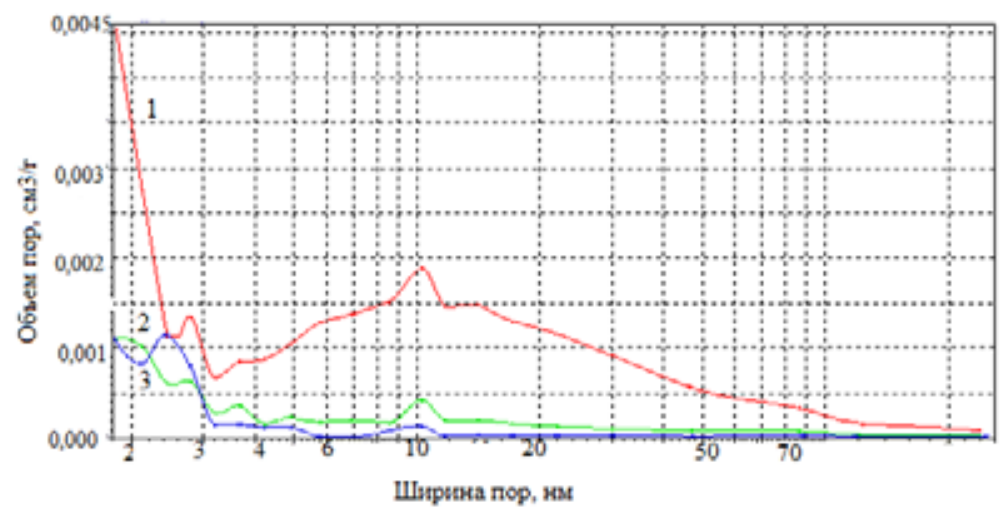

Рис. 5. Зависимость объёма пор от их ширины в образцах углеродных гелей, полученных карбонизацией ОГЛ, синтезированных при различных значениях $\mathrm{pH}: 1-4 ; 2-6,3-10$

Fig. 5. Dependence of the pore volume on the pore width in the carbon gels, obtained by carbonization of the OGL, synthesized at different $\mathrm{pH}$ values: $1-4 ; 2-6,3-10$

Таким образом, изменяя условия проведения процесса конденсации, в том числе величину pH исходного раствора, можно влиять на физико-химические свойства как органических гелей, так и получаемых из них углеродных гелей.

\section{Органические гели из смесей полифенолов и лигнина}

Введение технического лигнина - лигносульфоната - в качестве сополимера с полифенолами из коры лиственницы, выделенными экстракцией водой (ВПФЛ) либо 0,5\%-м раствором щелочи (ЩПФЛ), в значительной степени оказывает влияние на поведение полимерных компонентов в реакции конденсации и влияет на свойства конечных пористых продуктов. В табл. 2 представлены результаты изучения методом БЭТ текстурных характеристик лигнинполифенол-формальдегидных органических гелей, синтезированных при постоянном массовом соотношении (Л + ПФЛ $/ \Phi=1,5$, но при различном количестве лигнина, варьируемого в интервале 0,1:1 - 0,3:1.

Из анализа результатов табл. 2 следует, что в отсутствие добавок лигнина и в кислой (катализатор $\mathrm{H}_{2} \mathrm{SO}_{4}$ ), и в щелочной (катализатор $\mathrm{NaOH}$ ) средах получаются хрупкие, низкопористые продукты конденсации как с водными (образец 1), так и со щелочными (образец 5) экстрактами полифенолов коры лиственницы. Введение лигнина в количестве 10 \% вес. в случае ВПФЛ (образец 2) позволяет многократно увеличить удельную поверхность (в 17 раз), повысить общую пористость (в 2 раза) и общий объем пор (в 3,6 раза). Полученный продукт представляет собой полимерный материал, упругий и достаточно прочный, хорошо поддающийся формованию в виде блоков.

Дальнейшее увеличение содержания лигнина в реакционной смеси до 20-30\% вес. не приводит к дальнейшему развитию пористости. Напротив, для образцов 3 и 4 наблюдается снижение величины удельной поверхности с 25 до 10 и $5 \mathrm{~m}^{2} /$ г соответственно. При этом общая пористость образцов уменьшается вдвое, а общий пористый объем снижается почти в 4 раза. Полимерные материалы, содержащие повышенную концентрацию лигнина, подвергаются сильной усадке и сжимаются при сушке, а также отличаются меньшей прочностью. 
Таблица 2. Текстурные характеристики образцов органических гелей из смеси полифенолов и лигнина Table 2. Texture characteristics of the organic gels samples from polyphenols and lignin mixtures

\begin{tabular}{|c|c|c|c|c|c|c|c|}
\hline $\begin{array}{l}\text { №/ } \\
\text { № }\end{array}$ & Образец & $\begin{array}{c}\text { Лигнин, \% } \\
\text { вес }\end{array}$ & $\mathrm{S}_{\text {Бэт }}, \mathrm{M}^{2} / \Gamma$ & 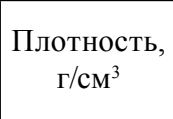 & $\begin{array}{c}\text { Общая } \\
\text { пористость, } \\
\text { W, \% отн. }\end{array}$ & $\begin{array}{c}\text { Общий } \\
\text { пористый } \\
\text { объем, } \mathrm{cm}^{3} / \Gamma\end{array}$ & *Катализатор \\
\hline 1 & ВПФЛ/Ф & - & 1,5 & 1,09 & 27 & 0,25 & $\mathrm{H}_{2} \mathrm{SO}_{4}$ \\
\hline 2 & (Л+ВПФЛ)/Ф & 10 & 25,0 & 0,55 & 63 & 1,05 & $\mathrm{H}_{2} \mathrm{SO}_{4}$ \\
\hline 3 & $($ (Л+ВПФЛ)/Ф & 20 & 10,0 & 0,96 & 36 & 0,37 & $\mathrm{H}_{2} \mathrm{SO}_{4}$ \\
\hline 4 & (Л+ВПФЛ)/Ф & 30 & 5,0 & 1,04 & 31 & 0,29 & $\mathrm{H}_{2} \mathrm{SO}_{4}$ \\
\hline 5 & ЩПФЛ/Ф & - & 1,1 & 0,80 & 47 & 0,58 & $\mathrm{NaOH}$ \\
\hline 6 & (Л+ЩПФЛ)/Ф & 10 & 1,6 & 0,82 & 45 & 0,55 & $\mathrm{NaOH}$ \\
\hline 7 & (Л+ЩПФЛ)/Ф & 20 & 2,2 & 0,75 & 50,0 & 0,66 & $\mathrm{NaOH}$ \\
\hline 8 & (Л+ЩПФЛ)/Ф & 30 & 5,7 & 0,69 & 54 & 0,78 & $\mathrm{NaOH}$ \\
\hline
\end{tabular}

*ВПФЛ-полифенолы лиственницы, экстрагированные водой, катализатор $\mathrm{H}_{2} \mathrm{SO}_{4}$; ЩПФЛ-полифенолылиственницы, экстрагированные 0,5 \% раствором щелочи, катализатор $10 \% \mathrm{NaOH}$; Л - лигносульфонаты.

*WPFL - larch polyphenols extracted with water, catalyst $-\mathrm{H}_{2} \mathrm{SO}_{4}$; APFL - larch polyphenols extracted with $0.5 \%$ alkali solution, catalyst $-10 \% \mathrm{NaOH}$; L - lignosulfonates.

Эти изменения, возможно, вызваны ассоциированием макромолекул лигносульфонатов, длина цепи которых и молекулярная масса выше, чем у таннинов [12]. Образование ассоциатов при возрастании концентрации лигносульфонатов в смеси может препятствовать пространственной ориентации макромолекул в объеме раствора и создавать стерические препятствия для участия реакционно-способных групп в реакциях полимеризации.

В случае щелочных экстрактов полифенолов также выявлено влияние лигнина на текстуру получаемых органических гелей, хотя оно и менее выражено, чем при использовании водных полифенолов (см. табл. 2). Действие вводимой добавки лигнина в щелочной среде становится заметным при увеличении его количества в смеси до 20-30 \%. Оно противоположно действию добавки лигнина в кислой среде, а именно с ростом количества лигнина от 10 до 30 \% наблюдается последовательное возрастание величины удельной поверхности (в 5 раз), увеличение пористого объема на 34 \% отн. при одновременном снижении плотности гелей.

Причиной снижения эффективности процесса гелеобразования с участием щелочных полифенолов, по-видимому, является более низкое содержание таннинов в водно-щелочном экстракте по сравнению с их содержанием в водном экстракте [13]. Относительное снижение концентрации реакционно-способных таннинов (пирокатехинов) в массе сухих веществ, экстрагированных из коры лиственницы водно-щелочным раствором, с одновременным извлечением других высокомолекулярных фракций, в том числе лигнина, приводит к фактическому изменению соотношения реагирующих компонентов. Кроме того, известно, что в присутствии щелочного катализатора (КОН) возможно протекание двух конкурирующих реакций: деполимеризации конденсированных полифенолов и их конденсации с формальдегидом, что также приводит к понижению числа эффективных сшивок с формальдегидом [14]. При этом получаемые гели становятся более хрупкими

Существенные различия в ИК-спектрах органических гелей, содержащих различные количества лигнина, отсутствуют (рис. 6), несмотря на очевидное влияние концентрации лигни-

$$
-376-
$$




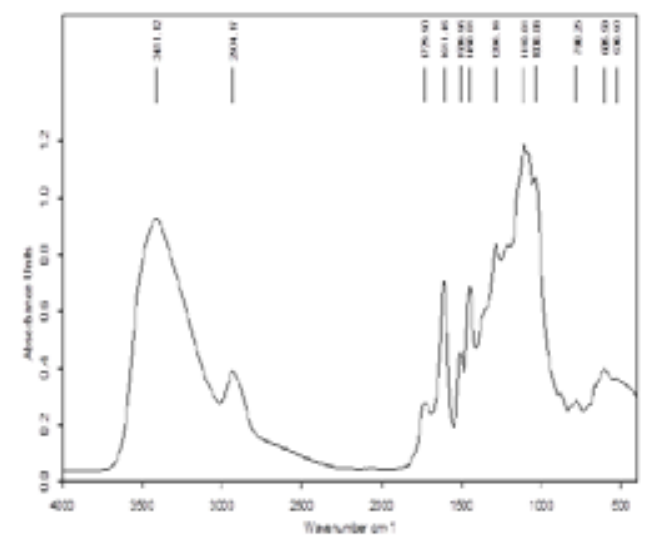

a

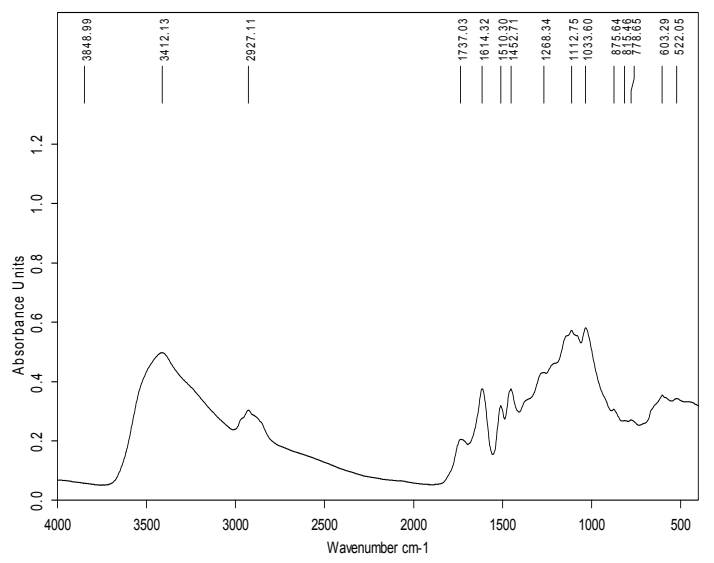

6

Рис. 6. ИК-спектры образцов лигнин-полифенол-формальдегидных органических гелей на основе ВПФЛ с содержанием лигнина 10 вес \% (а) и 30 вес \% (б)

Fig. 6. IR spectra of samples of lignin-polyphenol-formaldehyde organic gels based on WPFL with lignin content $10 \%$ wt. (a) and $30 \%$ wt. (b)

на на свойства гелей. В ИК-спектрах присутствуют полосы поглощения в областях 1611-1616, 1504-1516, 1450-1454 и 1424-1426 см-1, присущие ароматическому кольцу. Сочетание указанных полос с группой п.п. в области $875-778$ см$^{-1}$, связанных с колебаниями С-Н-связей, характеризует наличие замещенных ароматических конденсированных систем [15]. Интенсивные п.п. при $1737 \mathrm{~cm}^{-1}$ относятся к $\mathrm{C}=\mathrm{O}$-колебаниям преимущественно в сложноэфирных группах [13]. Сильное поглощение в областях спектров исследуемых гелей между 1200 и $1000 \mathrm{~cm}^{-1}$, возможно, вызвано C-O-C-колебаниями метиленовых эфирных мостиках типа - $\mathrm{CH}_{2}-\mathrm{O}-\mathrm{CH}_{2}-$, участвующими в образовании трехмерной сетчатой структуры геля, либо валентными С-О колебаниями в сложноэфирных группах [16]. Поглощение, наблюдаемое при $1210 \mathrm{~cm}^{-1}$, может быть отнесено к сульфокислотам [17].

По мере повышения содержания лигнина в смеси от 10 до 30 \% вес в ИК-спектре полученного геля усиливается поглощение в области $1280-1030 \mathrm{~cm}^{-1}$. Поглощение при $1280 \mathrm{~cm}^{-1}$ может быть отнесено к асимметричным C-O-С-колебаниям в метоксильных группах, а п.п. при $1033 \mathrm{~cm}^{-1}$ - к СО-валентным колебаниям в спиртах и эфирах, связанных с ароматическим ядром. Полоса при 1268 см$^{-1}$, вероятно, принадлежит скелетным колебаниям гваяцильных структур [16].

Можно ожидать, что введение достаточно крупных макромолекул лигнина в качестве сополимера для реакции гелирования в количестве 10-30 \% вес. приводит к пространственному «разбавлению» смеси за счет стерических эффектов и способствует образованию $\mathrm{C}-\mathrm{O}-\mathrm{C}-$ связей в арильных эфирах.

\section{Углеродные гели из смесей полифенолов и лигнина}

Карбонизация лигнин-полифенол-формальдегидных гелей способствует развитию пористой структуры в углеродных полимерных гелях, полученных из ВПФЛ (табл. 3). Наибольшее значение удельной поверхности (около $100 \mathrm{~m}^{2} / \Gamma$ ) наблюдается для образца УГ-2,

$$
-377-
$$


Таблица 3. Текстурные характеристики и выход углеродных гелей

Table 3. Texture characteristics and the yield of the carbon gels

\begin{tabular}{|c|l|c|c|c|c|c|}
\hline Образец & $\begin{array}{c}\text { Предшественник } \\
\text { углеродного геля }\end{array}$ & Лигнин, \% вес & $\mathrm{S}_{\text {Бэт, }}{ }^{2} / \Gamma$ & $\begin{array}{c}\text { Плотность, } \\
\text { Г/см }\end{array}$ & $\begin{array}{c}\text { Общая } \\
\text { пористость, } \\
\text { W, \% отн. }\end{array}$ & Выход УГ, \% \\
\hline УГ-1 & ВПФЛ/Ф & нет & 3 & 0,64 & 57 & 45,0 \\
\hline УГ-2 & Л+ВПФЛ/Ф & 10 & 99,5 & 0,61 & 59,6 & 42,4 \\
\hline УГ-3 & Л+ВПФЛ/Ф & 20 & 13,8 & 0,94 & 63,0 & 44,1 \\
\hline УГ-4 & Л +ВПФЛ/Ф & 30 & 14,2 & 0,87 & 62,0 & 43,0 \\
\hline
\end{tabular}

приготовленного из органического предшественника с содержанием лигнина $10 \%$ вес. Образцы углеродных гелей, содержащие 20 и 30 \% лигнина, имеют невысокую поверхность (около $14 \mathrm{~m}^{2} / \Gamma$ ).

Выход углеродных гелей составляет 40,2-45 \%, что находится в хорошем соответствии с известными примерами получения углеродных материалов из природных полифенолов [9, $18]$.

Проведение дополнительных исследований по изучению влияния добавок лигнина на свойства органических и углеродных гелей из растительного сырья позволит достичь лучшего понимания роли лигнина в регулировании свойств полученных пористых материалов и расширить области использования технических лигнинов.

\section{Выводы}

Установлено влияние природы исходных полифенолов, состава исходной смеси и условий конденсации на формирование пористой структуры и свойства органических и углеродных гелей, получаемых на основе полифенолов коры лиственницы и лигносульфонатов.

Показана возможность регулирования пористой текстуры полимерных гелей на основе этанольных экстрактов полифенолов коры лиственницы путем вариации $\mathrm{pH}$ исходной смеси полифенолы-формальдегид. Найдены условия получения гелей с удельной поверхностью до 477 м²/г и узким распределением мезопор по размерам.

Установлено, что добавки лигносульфонатов влияют на формирование пористой структуры продуктов конденсации полифенолов с формальдегидом. Введение лигнина в количестве 10 \% вес. к «водным» полифенолам коры лиственницы улучшает качество получаемых органических и углеродных гелей, а именно увеличивает их удельную поверхность и общую пористость, повышает упругость и прочность. Однако повышение лигнина в смеси до 20-30 \% вес. уменьшает общую пористость и общий объем, а также снижает прочностные и адсорбционные свойства гелей.

Влияние лигнина на пористую текстуру органических гелей, полученных поликонденсацией формальдегида со щелочными экстрактами полифенолов коры, менее выражено, чем в случае водных экстрактов полифенолов. Увеличение содержания лигнина в гелях из щелочных полифенолов с 10 до $30 \%$ вес. приводит к возрастанию удельной поверхности органических гелей с 1,1 до 5,7 м²/г, а углеродных гелей - с 5 до $40 \mathrm{~m}^{2} /$ г.

$$
-378-
$$


Исследование выполнено за счет гранта Российского научного фонда (проект № 16-1310326).

\section{Список литературы}

1. Гордиенко И.И., Федорова Т.Е., Иванова С.З., Бабкин В.А. Влияние экстрагента на компонентный состав фенольного комплекса, извлекаемого из коры лиственницы Гмелина. Химия растительного сырья. 2008. № 2, С. 35-38 [Gordienko I.I. Fedorova T.E., Ivanova S.Z., Babkin V.A. Effect of the extractant on the component composition of the phenolic complex extracted from the bark of Gmelin larch. Chemistry of plant raw materials. 2008. No. 2, P. 35-38. (In Russ.)].

2. Иванова С.3., Федорова Т.Е., Иванова Н.В., Федоров С.В., Остроухова Л.А. Флавоноидные соединения коры лиственницы сибирской и лиственницы Гмелина. Химия растительного сырья. 2002. № 4, C. 5-13. [Ivanova S.Z., Fedorova T.E., Ivanova N.V., Fedorov S.V., Ostroukhova L.A. Flavonoid compounds of the bark of Siberian larch and the Gmelin larch. Chemistry of plant raw materials. 2002. No. 4, P. 5-13. (In Russ.)].

3. Гончарова Н.В., Ток М.В., Рязанова Т.В. Влияние продолжительности экстракции на состав водно-щелочных экстрактов лиственницы сибирской. Химия растит. сырья. 1998. № 2. С. 75-78. [Goncharova N.V., Tok M.V., Ryazanova T.V. Effect of duration of extraction on the composition of the aqueous-alkaline extracts of Siberian larch. Chemistry of plant raw materials. 1998. No. 2, P. 7578 (In Russ.)]

4. Rey-Raap N., Arenillas A., Menendez J.A. RF xerogels with tailored porosity over the entire nanoscale. Microporous and Mesoporous Material. 2014. Vol. 195, P. 266-275.

5. Amaral-Labat G., Grishechko L.I., Fierro V., Kuznetsov B.N., Pizzi A., Celzard A. Tanninbased xerogels with distinctive porous structures. Biomass and bioenergy. 2013. Vol. 56, P. 437-445.

6. Delgado-Sanchez C., Amaral-Labat G., Grishechkoa L.I., Sanchez-Sanchez A., Fierro V., Pizzi A. and Celzard A. Fire-resistant tannin-ethylene glycol gels working as rubber springs with tuneable elasticproperties. Journal of Materials Chemistry A. 2017. Vol. 5, P. 14720-14732.

7. Grishechko L.I., Amaral-Labat G., Szczurek A., Fierro V., Kuznetsov B.N., Celzard A. Ligninphenol-formaldehyde aerogels and cryogels. Microporous and Mesoporous Materials. 2013. Vol. 168, P. 19-29.

8. Nishida M., Uraki Y., Sano Y. Lignin gel with unique swelling property. Bioresource Technology. 2003. Vol. 88, P. 81-83.

9. Wu D., Fu R., Sun Z., Yu Z. Low-density organic and carbon aerogels from the sol-gel polymerization of phenol with formaldehyde. J. Non-Crystalline Solids. 2005. Vol. 351, P. 915-921.

10. Бравко О.С., Паламарчук И.А., Вишнякова А.П. Влияние молекулярной массы лигносульфоната натрия на комплексообразование с полиэтиленполиамином. Химия растительного сырья. 2011. № 1, С. 65-70. [Bravko O.S., Palamarchuk I.A., Vishnyakova A.P. The influence of the molecular weight of sodium lignosulfonate on complex formation with polyethylene polyamine. Chemistry of plant raw materials. 2011. No. 1, P. 65-70 (In Russ.)].

11. Pandey K.K. A study of chemical structure of soft and hardwood and wood polymers by FTIR spectroscopy. Journal of Applied Polymer Science. 1999. V. 71(12), Р. 1969-1975.

12. Болатбаев К.Н., Луговицкая Т.Н., Колосов А.В. Идентификация и физико-химические свойства лигносульфонатов в растворах. Ползуновский вестник. 2009. № 3, С. 308-312.

$$
-379-
$$


[Bolotbaev. K.N., Luhovitskaya T.N., Kolosov A.V. Identification and physico-chemical properties of lignosulfonates in solution. The Polzunovskii Vestnik. 2009. No. 3, P 308-312. (In Russ)].

13. Левин Э.Д., Астанкович И.И., Рязанова Т.В. Состав спирто-щелочного экстракта коры лиственницы сибирской. Химия древесины. 1985. № 6. С. 101-104 [Levin E.D., Astankovitch I.I., Ryazanova T.V. The composition of the alcohol-alkaline extract of Siberian larch bark. Chemistry of wood. 1985. No. 6, P. 101-104. (In Russ)].

14. Левданский В.А., Бутылкина А.И., Кузнецов Б.Н. Выделение и изучение состава антоцианидинов коры лиственницы. Химия растительного сырья. 2006. № 4, С. 17-20. [Levdanski V.A., Butylkina A.I., Kuznetsov B.N. Chemistry of plant raw materials. 2016. No 4, P. 17-20. (In Russ.)].

15. Базарнова Н.Г, Карпова Е.В., Катраков И.Б., Маркин В.И., Микушина И.В., Ольхов Ю.А., Худенко С.В. Методы исследования древесины и ее производных. Под ред. Н.Г. Базарновой. Барнаул: Изд-во Алт. гос. ун-та, 2002. 160 с. [Bazarnova N,G . Karpova E.V. Katrakov I. B., Markin V.I., Mikushiha I.V., Olkhov, Y.A., Khudenko.S.V. Research methods of wood and its derivatives etc.; ed.G. Bazarnova. Barnaul: Publishing house Alt. state University, 2002. 160 p. (In Russ.)].

16. Cagniant D., Magri P., Bimer J., Gruber R. Nitrogen enriched active carbon precursors ammoxidation of carbonaceous materials: cellulose, lignin and pine sawdust. In: Proc. Carbon. 2003, Oviedo, Spain.

17. Sharma R.K., Wooten J.B., Baliga V.L., Lin X., Chan W.G., Hajaligol M.R. Characterization of chars from pyrolysis of lignin Fuel. 2004. Vol. 83, P. 1469-1482.

18. Grishechko L.I., Amaral-labat G., Szczurek A., Fierro V., Kuznetsov B.N., Pizzi A., Celzard A. New tannin - lignin aerogels. Industrial Crops \& Products 2013. Vol. 41 P. 347-355. 